\section{Decrease in the Value Relevance of Accounting Information in Electric Distributors after the Brazilian IFRS adoption}

\author{
Eduardo Flores ${ }^{1}$ \\ Alexsandro Broedel Lopes ${ }^{1}$ \\ ${ }^{1}$ University of São Paulo, FEA-USP, Department of Accounting \\ and Actuarial, São Paulo - Brazil
}

Received on

03/14/2018

Approved on

03/07/2019

\section{Responsible editor:}

Prof. Dr. Ivam Ricardo

Peleias

Evaluation process:

Double Blind Review

\begin{abstract}
Purpose - The present study evaluated whether there were reductions in the relevance of the accounting information of Brazilian energy distributors in the post-IFRS period.

Design/methodology/approach - The rationale for such a conjecture stems from the fact that after the adoption of international accounting standards, energy distributors were unable to register regulatory assets and liabilities concerning their activities. Besides, the same hypothesis was also evaluated for Canadian electricity incumbents. The inclusion of the Canadian companies in this study was the result of the permission given by the IASB, through IFRS 14 , so that adopters of international standards from 2015, could continue to register the regulatory items.
\end{abstract}

Findings - Using a value relevance model it was possible to conclude that there was a reduction in the relevance of the accounting information in the Brazilian case and that this decrease is very potentially related to the write-off of regulatory assets after IFRS. It was also observed that the same effect did not occur in the Canadian companies after the adoption of this normative set. It was also verified that before the IFRS, both the regulatory assets of Brazilian companies and of Canadian firms, were from the statistical perspective also incorporated into the market value of the companies analyzed, denoting similar behavior on the part of investors.

Originality/value - That is, although the economies of these jurisdictions are distinct, investors incorporated such accounting assets into stock prices because they could potentially verify realization rates on such items. Thus, it is concluded that the adoption of international standards did not benefit Brazilian energy distributors by distancing the book value from their market value.

Keywords - Regulatory assets; Relevance of Accounting Information; Brazil; Canada; IFRS 14.

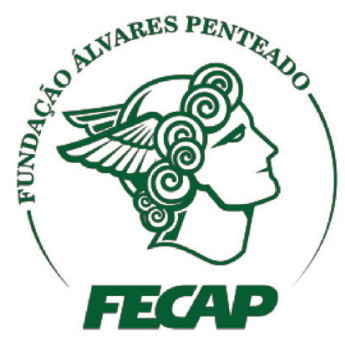

\section{Review of Business Management}

DOI: $10.7819 /$ rbgn.v21i5.4023 


\section{Introduction}

The primary objective of financial statements is to provide information on the financial position, performance, and changes in this position of an entity, which are relevant to a wide variety of users in their economic decisionmaking (IASB, 2010). In a complementary idea to this, Horngren, Harrison, and Robinson (1995, p. 4) mention that accounting: "is the system that measures business activities, processes that information, and communicates the results to decision makers. For this reason, it is called the language of business."

However, it is essential to mention that: "accounting is an artifact, a product of human intervention designed for human purposes" (Parker, Ferris, and Otley, 1989, p. 1). In this sense, the preparation of financial statements occurs in large part through the exercising of subjective choices by management, choices which are supposed to reflect the best measurements and knowledge about economic and financial events that impact organizations.

In this context, it is possible to restrict the scope to the capital market agents' perspective, where such information plays a prior role in investor predictions of the future returns of organizations, where such expectations are expressed in stock prices and returns. A sample of works from this line of research can be found in the studies by Ball and Brown (1968), Beaver, (1968), Francis and Schipper (1999), and Holthausen and Watts (2001), among others.

In order to increase the relevance of accounting information, some jurisdictions have adopted international financial reporting standards (IFRS), including Brazil.

Lima (2010) points out that after the adoption of IFRS in Brazil, financial statements showed greater relevance as the book value drew closer to the market value of listed companies.

However, the same effect did not occur in electricity distributors. After the full adoption of the international standards in 2010, these companies were obliged to withdraw from their statements the regulatory asset and liability components that derive from the way their activities are conducted.

The Brazilian Electricity Regulatory Agency (ANEEL) intervened in this impediment through Normative Resolution n. 396 of 2010, given the need and importance, according to their understanding, to keep a book record of regulatory items.

These regulatory items were verified as imperative to determining the market value of US electricity incumbents, especially regulatory assets (Loudder, Khrunana, and Boastman, 1996).

In this context, the research question of this study is: did the adoption of IFRS lead to a reduction in the relevance of the accounting information of Brazilian electricity distributors due to the impossibility of recognizing regulatory assets?

Due to this situation, regulatory items gained greater prominence with the issuance of IFRS 14 Regulatory Deferral Accounts. This accounting rule allowed rate-regulated firms located in countries who adopted IFRS after 2015 to keep their regulatory items on their balance sheets. According to Pacter (2017), Canada adopted IFRS in that year.

This context created the possibility of analyzing a significant counterexample for this study, allowing a comparison of the effects of the adoption of IFRS on the value relevance of Brazilian distributors with Canadian firms in the same industry.

Our results indicated no significant reduction in the relevance of the accounting information of electricity distributors and that this did not occur in Canada, thus confirming that the effect of non-recognition of regulatory assets negatively affected those companies in Brazil.

Furthermore, to assess if the regulatory environment could interfere in the incorporation or not of regulatory assets in the market value of these companies, the relevance of such items in the period before IFRS was evaluated for both Brazilian and Canadian companies. The results 
indicated that in both cases these assets were contained in the stock prices, without denoting statistically significant differences between them.

The remainder of this paper is subdivided as follows: 2 - review of the literature regarding the formation of rates in the electricity sector in Brazil, including the history of the adoption of IFRS for this economic sector and the permissive effects of IFRS 14, as well as the econometric model used to test the established hypotheses; 3 - methodological attributes; 4 - descriptive statistics and results; and 5 - final considerations.

\section{Background and Hypotheses Development}

This section will present the main theoretical arguments involving the accounting recognition of the regulatory items of electric power distributors, as well as their interaction with the value relevance literature.

\section{I Regulatory items of electric power distributors in Brazil}

According to CPC Orientation 08 (OCPC $08,2014)$, the regulatory items of the electricity sector arise due to how ANEEL establishes the remuneration of the incumbents. In general terms, the revenues of the electric power distribution concessionaires are basically composed of the sale and delivery of electrical energy using an infrastructure. Thus, revenues are affected by the volume of energy delivered and the rate.

The electricity rate consists of two parts that reflect the composition of revenue, these being: (i) portion A, related to non-manageable costs, which are formed of the costs of acquiring electrical energy; and (ii) portion B, which is denominated manageable costs, whose formation stems from investments in infrastructure (CPC, 2014).

According to Tancini (2013), the regulatory items arise in portion $A$, representing the costs based on forecasts of electricity demand. Regulatory assets represent a right to receive when the costs incurred are higher than the estimated costs; otherwise there is a regulatory liability.
It should be noted that the regulatory items became useful as assets and liabilities of distributors in 2001, arising from ANEEL's guidance, which was substantially based on the US standard SFAS 71 - Accounting for the Effects of Certain Types of Regulation, issued in the 1980s. According to the IASB (2014): “[...] in 1982, the US national standard-setter, the Financial Accounting Standards Board (FASB), issued SFAS 71 [...] SFAS 71 formalized many of those principles. In the absence of specific national guidance, practice in many other jurisdictions followed SFAS 71."

However, such regulatory items are no longer recorded in Brazilian accounting statements.

According to the Accounting Pronouncements Committee (OCPC 08, 2014), these items are no longer eligible for such purposes after the adoption of IFRS in 2010, for three reasons, these being: (i) the future delivery of electrical energy is a future event that is not adequately controlled by the entity; (ii) at the time of the appearance of the regulatory items it is not practicable to know if and which buyers would or would not benefit from this difference; and (iii) there was no consensus as to whether the legislation in force at the time would support receipts or would require payments arising from such a temporal mismatch.

Item IN7 of OCPC 08 sets forth the following statement of reasons why regulatory items are no longer recognized in financial statements after the adoption of IFRS:

IN7. After adopting international accounting standards - IFRS - in Brazil, as of 2010, the general purpose accounting and financial reports of these concessionaires no longer contemplate the recognition of these assets and/or liabilities based on the understanding that these rights and obligations do not fully meet the definitions of assets and liabilities contained in the Conceptual Framework for Preparation and Disclosure of Financial Reporting. Such an understanding stems from the fact that (i) their realization or liability 
would depend on a future event not fully controllable by the entity - the future delivery of electrical energy; and (ii) it is not practicable to know, at the time of the emergence of such rights or obligations, if the actual purchasers of that energy in the future would pay those differences or have them returned in their electricity bills. (OCPC 08, page 2).

It should be emphasized that this impossibility of recognition of regulatory items was not accepted equally by the agents participating in the 'productive chain' of accounting information. ANEEL, for example, established regulatory accounting, where one of the main objectives listed in the second paragraph of Normative Resolution n. 396 of 2010 is: "the need to maintain the accounting information related to the composition of the assets related to the concession, permission, and authorization of electrical energy [...] in view of the imminent changes proposed for the convergence of Brazilian accounting practices with international accounting standards [...]."

According to Resolution 396, the recognition of regulatory items stems from the need to present a set of information that adequately represents the economic and financial situations of electrical energy concessionaires and licensees (ANEEL, 2010). In summary, under the regulator's understanding, regulatory items are fundamental for financial statements to be faithful to the economic events they intend to represent.

\subsection{The value relevance of the accounting information on regulatory items for electricity distribution firms}

A wide range of studies has sought to demonstrate the effect of financial statements, as well as of specific elements of them, in relation to the market value of publicly-traded companies (e.g. Ball and Brown, 1968; Beaver, 1968; Francis and Schipper, 1999; Holthausen and Watts, 2001; Barth et al., 2001; Lopes, 2001; Barth and Clinch, 2009; Lima, 2010). This way of conducting accounting research is especially useful to verify the effect of a given standardization that requires or prevents a given treatment, from a capital market perspective.

According to Scott (2012), as accounting standards change there are at least four reasons that justify changes in investor behavior that affect stock prices, these being: (i) new accounting information may alter investors' expectations about the future cash flows of organizations; (ii) once the results have been published, market agents compare their forecasts and change prices by virtue of the degree of accuracy and predictability of the results; (iii) prospects such as the propensity to sell or purchase a particular share may change as a result of the accounting numbers determined in accordance with new rules; and (iv) accounting information can affect the volume of trading.

Amir et al. (1993), Easton et al. (1993), Ohlson (1995), Barth and Clinch (1996), Aboody et al. (1999), and Lopes and Walker (2012) reveal that there is a positive and significant association between stockholders' equity, earnings, and the share price. That is, the equity component of the balance sheet and the disclosed earnings are contained in stock prices.

In this context, this is what the accounting research has called value relevance. It should be noted that relevance here is attributed to the capital market agents.

The question of the informational relevance of regulatory items, more specifically of regulatory assets, was initially researched by Loudder, Khrunana, and Boastman (1996), in relation to the US utilities sector. These authors assessed whether the regulatory environment, ranging from more concessional to more restrictive, as regards the possibility of recovering regulatory assets through rates, interferes with market valuations and, consequently, the incorporation of these assets into stock prices.

Starting from the algebraic notation by Ohlson (1991), Loudder, Khrunana, and Boastman (1996) assumed the premise that the 
market value of a company's equity at time $t$ $\left(\mathrm{MVE}_{\mathrm{t}}\right)$ can be explained by its book value of equity $\left(\mathrm{BVE}_{\mathrm{t}}\right)$, earnings $\left(\mathrm{E}_{\mathrm{t}}\right)$, and dividends $\left(\mathrm{D}_{\mathrm{t}}\right)$, as denoted in Equation (1) below.

\section{$M V E_{t}=\beta_{1} B V E_{t}+\beta_{2} E_{t}+\beta_{2} D_{t}$}

Loudder, Khrunana, and Boastman (1996) adopted Equation (1) in order to apply the approach to the US utilities sector, dividing the term $\mathrm{BVE}_{\mathrm{t}}$ into two parts: $\mathrm{BVA}_{\mathrm{t}}$, related to total shareholders' equity minus the balance of the regulatory assets; and $\mathrm{RA}_{\mathrm{t}}$, which refers precisely to the amount of these assets, as shown in Equation (2).

$$
M V E_{\mathrm{t}}=B V A_{\mathrm{t}}+E_{\mathrm{z}}+D_{\mathrm{t}}+R A_{\mathrm{t}}
$$

Then, Loudder, Khrunana, and Boastman (1996) deflated the terms of Equation (2) by the total number of shares issued, as recommended by Barth, Beaver, and Stinson (1991), thus obtaining what in this study will be called the functional form of the model to evaluate the relevance of the accounting information on regulatory assets in terms of stock prices (Equation 4).

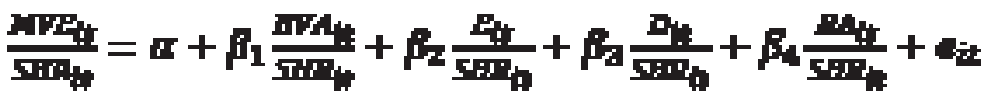

Here, $\beta$ represents the estimated parameters regarding the influence of the accounting numbers on the market value of company $i$ at time $t$; and SHR refers to the volume of issued shares used to deflate the variables (Barth, Beaver, and Stinson, 1991).

Loudder, Khrunana, and Boastman (1996, p. 357) state that: "Our results indicate that investors' valuation of regulatory assets depends on the regulatory environment in which the utility is operating." D'Souza (1998, p. 387) complements this perspective by mentioning that: "[...] managers of rate-regulated firms face greater uncertainties about future rate recoveries [...]."

Because of the results obtained by Loudder, Khrunana, and Boastman (1996), as well as the efforts made by ANEEL to maintain the accounting records of these items with regulatory statements, it is possible to establish the first hypothesis of this study:

H1 - The relevance of accounting information to the market value of Brazilian electrical energy distribution companies decreased after

\author{
the adoption of IFRS due to the derecognition \\ of regulatory assets.
}

It is important to emphasize that what we evaluated was not the ability or not of Brazilian capital market agents to incorporate regulatory items into stock prices, because this information became available through the regulatory accounting statements required by ANEEL. Our focal point consisted in analyzing the effect of the write-off of regulatory items in terms of decreasing or not the informational relevance of the financial statements presented to the CVM in the periods before and after IFRS, vis-à-vis the explanatory potential of the use of such reports with regard to stock prices.

That is, considering that the information set forth in the financial statements addressed to the CVM, prior to the adoption of IFRS, contained information on regulatory items and that such assets and liabilities were derecognized after the adoption of international standards, thereby affecting shareholders' equity, we seek to assess the effect of this write-off for the purposes of 
explaining share prices based on such information, without assuming that agents could not access it in other ways, but instead considering that they could not do so any more by means of corporate balance sheets.

\subsection{The non-cut-off effect of regulatory assets after IFRS adoption in Canada}

Until 2014, any discussion of nonrecognition of regulatory items was strictly technical. However, in the same year, the IASB issued IFRS 14 - Regulatory Deferral Accounts. The primary function of this standard was to allow companies with regulated charging activities to adopt international standards from 2015 , and to maintain their regulatory items recorded in the books.

IN2 This Standard permits a first-time adopter within its scope to continue to account for regulatory deferral account balances in its first IFRS financial statements under its previous GAAP when it adopts IFRS. However, IFRS 14 introduces limited changes to some previous GAAP accounting practices for regulatory deferral account balances, which are primarily related to the presentation of these accounts. (IASB, 2014, A641).

Such permission was understood as a concession for Canada to migrate its accounting to the guidelines established by the IASB. This interpretation is not related to conspiracy readings of the subject, given that the IASB itself indirectly recognized this fact in the basis for the conclusions of IFRS 14.

BC13 The IASB recognizes that discontinuing the recognition of regulatory deferral account balances in advance of the conclusion of the comprehensive Rateregulated Activities project could be a significant barrier to the adoption of IFRS for entities for which regulatory deferral account balances represent a significant proportion of net assets. This has led to an industry-specific 'carve-out' from the application of IFRS in at least one jurisdiction that has otherwise adopted IFRS, to allow rate-regulated entities to continue to use local GAAP (or, in some cases, US GAAP). In addition, there are examples of 'carve-ins' being created that introduce specific guidance for rate-regulated activities that overlies IFRS requirements as issued by the IASB. However, the interaction of such guidance when it conflicts with the requirements of IFRS can create a diversity of application in practice. (IASB, 2017, p. B1471).

According to Torres (2014), the IASB's decision to make an exception regarding regulatory items to attract Canada to IFRS adoption caused great discomfort among those involved in the process of publishing accounting standards in Brazil. Torres (2014) points out that although the members of the IASB do not explicitly say so, it is well known in the accounting community that IFRS 14 emerged to attract Canada. According to the journalist, the change also pleased the United States, which allows the recording of regulatory assets. However, if the purpose of IFRS is to stimulate the comparability of balance sheets around the world, this exception for new users does not seem to make sense (Torres, 2014).

Recently, the topic has returned to the agenda in the discussions by a technical article produced by the Canadian Accounting Standards Board (AcSB), whose objective was to promote discussion by the Accounting Standards Advisory Forum (ASAF). In this material, the AcSB (2016, page 2) points out that one of the primary elements for identifying whether or not such items should be recognized in the books is the regulatory 
framework in which entities operate, given that the data demonstrate that the regulatory environment in which an electricity concessionaire operates is a key factor considered by both credit market analysts and the capital market, as well as rating agencies. According to the AcSB (2016), the analyses demonstrate that investors pay a higher value for shares of companies operating in robust regulatory environments because in such jurisdictions compliance with contractual clauses is more stable. For jurisdictions such as Canada and the US, which recognize the balances arising from rate regulation in financial statements, the purchase price allocations examined have shown that the book value of these balances generally comes close to their fair value (AcSB, 2016).

Such results are logical, since the impossibility of converting, for example, regulatory assets into cash would potentially imply a higher risk for investors, who would consider this element in security prices. However, it is important not to confuse a robust regulatory framework with a robust economy. Without sophisms, the US and Canadian economies are more stable than the Brazilian one. However, such an assumption cannot be made about the regulatory framework of the electricity sector.

A demonstration that the electricity sector in Brazil has robust guarantees on the assets held by the concessionaires in exchange for the granting of authority derives from how ANEEL and the Federal Government addressed the electricity crisis of the early 2000s. According to Tancini (2013), the intervention of the Federal Government through the Electricity Sector Agreement instituted by Law 10,438/2002, which established Extraordinary Rate Recomposition, guaranteed the economic-financial balance of electric energy concessionaires.

In addition, ANEEL's position in determining that regulatory items should continue to be recorded, even if in another set of financial statements, evidenced that, at least as far as the regulator is concerned, such items are not only relevant for informational purposes, but should also be backed by legal guarantees. This would indicate discontinuity of the current concession format of the electricity sector governed by law $8,631 / 1993$, subsequently supplemented by the laws 8,987/1995, 9,427/1997, and 9,648/1998.

Thus, it is possible to establish the second hypothesis of this study, which aims to compare the informational relevance of the regulatory assets of Brazilian companies with Canadian companies in the period preceding the adoption of IFRS in these jurisdictions.

H2 - Previous to the adoption of IFRS, regulatory assets had statistically the same informational relevance in both Brazil and Canada.

Finally, the third hypothesis is to evaluate if there were reductions in the relevance of the financial statements of Canadian companies linked to the electricity sector in the postIFRS period, given that IFRS 14 ensured the maintenance of the regulatory items in balance sheets.

H3-The relevance of accounting information
to the market value of Canadian electrical
energy companies did not change statistically
after the adoption of IFRS due to the
maintenance of regulatory assets under
IFRS 14.

\section{Methodology}

The descriptions below refer to the data collection, the variables, and the estimation format chosen to obtain the main results of this study. 


\section{I Data collection}

Due to the geographical dispersion of these organizations, it is possible to characterize this study as research that will use a cross-country analysis. Gordon et al. (2013) emphasize that the development of studies involving more than one jurisdiction allows for the existence of nuances and the permanence of similarities of the studied object, enabling a more detailed and robust investigation.

Also, it is important to mention that crosscountry studies for the purposes of evaluating the effects of adopting IFRS have been an accepted trend in research involving international accounting, primarily due to offering the possibility of comparing the effects of international standards in different economic and jurisdictional environments. An example of this can be found in the studies by Houque \& Monem (2016) and Ball, Li, \& Shivakumar (2016).

In brief, Houque \& Monem (2016) assessed the effects of adopting IFRS, as well as the extent and perception of corruption, in more than 104 countries from 2009 to 2011 . In this database are data from emerging countries such as Brazil, as well as data from developed countries such as Germany and the United Kingdom. It is also important to note that the European Union countries have already demanded IFRS for companies listed on their stock exchanges since 2005, whereas Brazil, for example, only came to fulfill this requirement in full after 2010. Within the sample period, the subprime crisis occurred, affecting the analyzed countries differently.

In turn, Ball, Li, \& Shivakumar (2016) assessed whether the adoption of IFRS increased the use of contractual covenants not based on figures drawn from financial statements. The authors used data from 43 countries from 2001 to 2010, which also mix different IFRS adoption periods in each locality, and local effects are controlled through country dummies considered as fixed effects controls.

In this way, it is possible to conclude that cross-country research using as an event the full or partial adoption of IFRS does not seek comparisons of different countries, but the research is more believable with the inclusion of robustness tests and control variables.

The data were collected through the Thomson Reuters Datastream provider, taking into account the variables established in Equation (3), plus an additional term called CON, representing a time dummy variable for the years 2008 and 2009. This term was only included for the sample of Brazilian companies, because in the national territory the decision to adopt IFRS began with the promulgation of Law 11,638 on December 28, 2007, which took effect in 2008 and 2009, with the partial translation of some accounting standards.

Table 1 shows the definitions of the variables, as well as the codes that these variables have on the Thomson Datastream platform. 
Table 1

Description of variables

Total book value of equity minus total regulatory assets for company $i$ at the end of period $t$, respectively divided
by the total number of shares issued by company $i$.

We consider as the moment of conversion the year 2010, when the financial statements of Brazilian publicly-held companies effectively became adherent to international standards.

Regarding the beginning of the period covered in the data collection, we chose 2002, since it was in this year that ANEEL began to demand the recognition of regulatory items, with the financial statements arising from the requirements established by Law 10,438/2002.

It should be emphasized that the regulatory assets of both the Brazilian and Canadian companies used in this study were analyzed through an individual analysis of the financial statements from 2002 to 2017 , in order to guarantee the robustness of the RA/SHR variable.

Likewise, in January and February of 2018 we find statements by the sampled companies from the period ending in 2017, which allowed for further expansion of the database.

Regarding the exclusion of observations, other electricity concessionaires from the electric power sector that were not distributors were initially taken out of the sample of Brazilian companies, as well as observations regarding companies that issued debt securities and nonshares. In the case of the Canadian companies, companies that issued debt securities were excluded, as were companies that were joint-listed.

In order to allow for comparisons between the estimated parameters, the collected data were converted into US dollars at the end of each fiscal year.

The final computation of observations for the Brazilian companies was 268 and 339 for the Canadian firms. Although the sample size is relatively small, it is important to emphasize that the work by Loudder, Khrunana, and Boastman (1996) was developed with a total of 988 observations collected from 1984 to 1993 , highlighting the fact that these authors investigated the North American market, recognized for its size, and also included gas companies, transmission companies, and electricity distributors. That is, for 
a study with such specificity, it is not surprising to obtain a reduced sample.

In addition, it is important to note that there were companies selected which are holding companies in the electricity sector, both among the Brazilian and Canadian companies.

\subsection{Fixed Effects Model}

Following the same approach advocated by Loudder, Khrunana, and Boastman (1996), a fixed effects model was used to optimize the iterations of the parameters.

Moreover, segregation of the sample sets into pre and post IFRS segments for each country and analyzing a single sector reduce the need for control terms, implying a lower consumption of degrees of freedom. This fact complements the choice of approach by Ohlson (1991), adjusted by Barth, Beaver, and Stinson (1991) and with adaptations by Loudder, Khrunana, and Boastman (1996).

The fixed effects model used here is a form of panel data estimation, which according to Duarte, Lamounier, and Takamatsu (2007, p. 3) can be represented by:

$y_{i t}=\beta_{o i t}+\beta_{1 i t} x_{1 i t}+\ldots \beta_{n i t} x_{k i t}+e_{i t}$

where the subscript $i$ denotes the different individuals, and the subscript $t$ denotes the period being analyzed. $\beta_{o}$ refers to the intercept parameter and $\beta_{k}$ to the angular coefficient corresponding to the $\mathrm{k}$-th explanatory variable.

There are different ways of estimating panel data models. Static models require more robust validations. According to Wooldridge (2010), the static term comes from contemporary relationships between dependent and independent variables. Thus, a static model is established when it is conjectured that a change in an independent term $z$ in period $t$ will have an effect on a dependent term $y$ at the same time: $\Delta y_{t}=\Delta \beta_{t} \Delta z_{t}$, when $\Delta \mathrm{ut}=0$ ".

Marques (2000, p. 9) emphasizes that among the different static models employed, the two most commonly used ones are the fixed effects model (FEM) and the random effects model (REM). The author advocates that the concept of fixed effects implies coefficients that can vary from individual to individual or in time.

Wooldridge (2010) denotes that the primary equation consists of the following notation:

$y_{i t}=\beta_{o}+\delta_{0} d_{2 \mathrm{t}}+\beta_{1} x_{1 i t}+\alpha_{i}+u_{i t}$

In it, the variable $\alpha \mathrm{i}$ captures all the unobserved factors that are constant in time and that affect $y_{i t}$. (The fact that $\alpha$ i does not have a subscript $t$ says that it does not change over time.) Generally speaking, $\alpha_{i}$ is called an unobserved effect.

In this context, the unobserved effects that affect the market value of the equity of the electricity sector companies composing the sample will be captured by the element $\alpha_{i}$, with the part of the variation resulting from regulatory assets remaining, which are explicit in the model through the RA/SHR variable.

\section{$3 \cdot 3$ Robustness tests}

In order to increase the reliability of the findings shown in the results section, we incorporated a section of robustness tests into the study, more specifically trying to mitigate the following aspects: (i) the risk of comparing different economic environments without due controls and the generation of spurious effects; and (ii) the effects of temporal idiosyncratic attributes on the countries analyzed.

In addition, a test was also introduced to mitigate the effects of the enactment of OCPC 08 in 2014, which set a precedent for accounting records of sectoral financial assets, thus allowing the recording of part of the items previously denominated as regulatory assets.

\subsection{Diff-in-DiffModel}

Because of the comparison of different countries adopting IFRS in different years, which 
can be considered as causing statistical bias in the results of the preceding equations, the following adaptation was established for the model used by Loudder, Khrunana, and Boastman (1996).

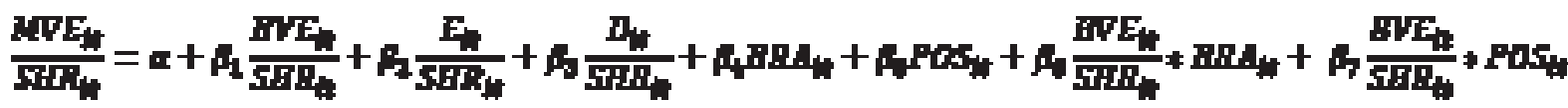

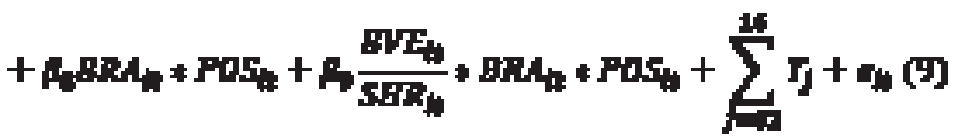

The insertion of the BRA binary variable, with 1 being for Brazilian companies and zero otherwise $^{1}$, had the purpose of attenuating the effects of the inclusion of observations from different economic environments in the same model. Based on this, the parameter tends to concentrate the effect of the variation in stock prices, considering the fact that certain companies in the database trade their shares in the Brazilian capital market, thus controlling the characteristic effects of each locality. Additionally, this variable also allows the use of Brazilian companies as a treatment group, since only energy distributors in Brazil were prevented from continuing to recognize regulatory items after the adoption of IFRS in 2010.

Subsequently, we inserted a binary variable called POS, which assumes the value 1 for the information referring to periods from 2010 and zero otherwise. Together with the BRA term, this variable was included in the model to allow the composition of a difference-in-differences analysis.

According to Angrist and Pischke (2009), the differences-in-differences models start from the assumption of the existence of a treatment group, which has experienced an exogenous shock, and a control group that has not experienced this shock (first diff), as well as the existence of time windows, preceding and following the occurrence of this event (second diff).

Applying this definition to the study, the treatment group is the Brazilian electricity distribution companies, which as of 2010 were prevented from continuing to record their regulatory items in the company financial statements. The control group is the Canadian companies in the same segment that did not suffer this deprivation (diff between groups).

Moreover, before the full adoption of IFRS in Brazil - before 2010 - both groups recorded the regulatory items in their balance sheets; however, the Brazilian companies had to proceed to write off these amounts after 2010 (temporal diff).

Subsequently, there is interaction between both the BRA and POS terms and BVE/SHR, which denotes the value of shareholder's equity per share of the companies. Interactions between the variables were taken at par, in order to mitigate their permutative effects, leaving the main interaction containing the three terms

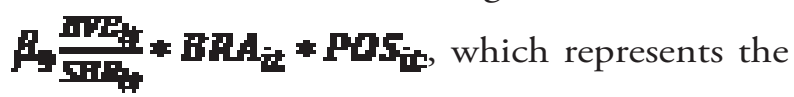
value of shareholders' equity (BVE) per share of the Brazilian electricity distributors (BRA), after the adoption of IFRS in 2010 (POS).

In logical-deductive terms, it is possible to establish that if the effect of accounting derecognition of the regulatory items of the Brazilian distributors analyzed caused a reduction of the relevance of the corporate accounting information, represented by shareholders' equity per share, compared with the Canadian companies in the post-IFRS period, then the estimated coefficient for $\beta_{\text {g }}$ should be negative and statistically significant.

It is also important to emphasize that earnings (E/SHR) and dividends (D/SHR) did 
not receive the same interactive treatment with BRA and POS, because the regulatory items were recorded in the balance sheet as assets and/ or liabilities, affecting shareholders' equity (BVE/ SHR).

Controls for the temporal context of the observations analyzed were also inserted in Equation (9). For both countries we consider information from 2002 to 2016, including dummy variables for each year, aiming to establish a temporal fixed effects control, denoted by

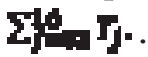

This procedure was incorporated into the test in order to control the idiosyncratic temporal effects of each jurisdiction that do not impact other localities, such as the decline in Brazilian GDP in 2015 and 2016, which does not affect Canadian companies. The control of the temporal transition helps in reducing the endogenous effects of each locality (ANGRIST and PISCHKE, 2009).

\subsubsection{Model contemplating Sectoral Financial Assets - OCPC 08}

Due to the controversy surrounding the write-off of the regulatory items in the financial statements presented in line with IFRS after 2010, on November 25, 2014, ANEEL performed the following procedure:

IN10. To reduce relevant uncertainties regarding the recognition and realization or settlement of regulatory assets and/ or liabilities and, consequently, qualify them as recognizable in the generalpurpose accounting-financial reports of the Brazilian electricity distribution concessionaires, ANEEL decided on November 25, 2014, with the full acceptance of each electric power concessionaire that wants to adhere, to add the concession agreements of the Brazilian electricity distribution companies. (OCPC 08, page 3).

As of the contractual amendment made in 2014, some of the regulatory items were returned to the balance sheet prepared following international standards, however together with the financial assets or liabilities items, according to item 13 of this same regulation.

13. Considering that the device added to the concession and permit contracts deals with the remaining balances calculated from Portion A items and other financial components that have not yet been recovered and, therefore, demand the implementation of this accounting practice of prospective application, the adjustment to be made must be recognized in financial asset or liability accounts, as the case may be, as a counter-entry to income for the year (revenue from selling goods and services) in which the contract modification occurs. (OCPC 08, page 6).

Considering this fact, we established Equation (10) with the inclusion of sectoral financial assets recognized in the balance sheets of Brazilian electricity distributors after 2014 .

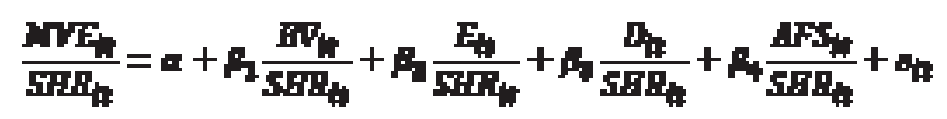

The variables MVE/SHR, E/SHR, and $\mathrm{D} / \mathrm{SHR}$ are used in the same way as in the other statistical procedures. The BV/SHR term refers to the book value of equity without regulatory assets from 2010 to 2013, and after that, net of the effects of sectoral financial assets arising from
OCPC 08, from 2014 to 2016, which precisely make up the AFS/SHR variable.

In this context, the robustness test expressed in Equation (10) aims to analyze whether the recording of sectoral financial assets could recover the informational relevance of 
the corporate balance sheet, potentially reduced with the adoption of international standards, in terms of stock prices. If this relationship was recovered through sectoral financial assets, which represent part of the old regulatory assets, the estimated parameter is expected to be positive and statistically significant.

\section{Results}

In this topic, we present the main statistical descriptions of the variables and the results obtained with the regressions of the models.

\section{I Descriptive Statistics}

We can verify in the window prior to the adoption of IFRS that the average market value of the Brazilian electricity distributors was higher than after the adoption (MVE/SHR before IFRS of 19.20 , dropping to 12.11 in the post-adoption period). It is important to emphasize that there is no suggestion that the adoption of the new accounting standard led to a reduction in the market value of these companies.

Strictly concerning accounting data, it is possible to verify that the equity value reduces after the adoption of IFRS from 11.74, before the new order, to 8.09. The same behavior is also verified in earnings per share (E/SHR), which goes from 3.02 to 2.91. Regarding dividends, there was an average increase from 1.41 to 1.56 .

Table 2

Panel A: Descriptive Statistics - Aiming to avoid column redundancy in the tables, we consider the main central tendency measure, as well as the most relevant variation indicator for each sample subset.

\begin{tabular}{lccc}
\hline \multicolumn{4}{c}{ Brazil - Pre-Adoption of IFRS (2002 to 2009) } \\
Variable & Obs. & Média & Std. Dev. \\
\hline MVE/SHR & 160 & 19,20 & 9,62 \\
BVA/SHR & 160 & 11,74 & 6,37 \\
E/SHR & 160 & 3,02 & 1,18 \\
D/SHR & 160 & 1,41 & 0,68 \\
RA/SHR & 160 & 2,29 & 2,07 \\
\end{tabular}

\begin{tabular}{lccc}
\hline \multicolumn{4}{c}{ Brazil - Post Adoption of IFRS (2010 to 2016) } \\
Variable & Obs. & Média & Std. Dev. \\
\hline MVE/SHR & 108 & 12,11 & 8,51 \\
BVE/SHR & 108 & 8,09 & 7,78 \\
E/SHR & 108 & 2,91 & 1,62 \\
D/SHR & 108 & 1,56 & 0,59
\end{tabular}

\begin{tabular}{lccc}
\hline \multicolumn{4}{c}{ Canada - Pre-Adoption of IFRS (2002 to 2014) } \\
Variable & Obs. & Média & Std. Dev. \\
\hline MVE/SHR & 224 & 28,50 & 10,09 \\
BVA/SHR & 224 & 16,31 & 4,92 \\
E/SHR & 224 & 3,69 & 1,41 \\
D/SHR & 224 & 1,84 & 0,59 \\
RA/SHR & 224 & 4,25 & 3,14 \\
\hline
\end{tabular}

\begin{tabular}{lccc}
\hline \multicolumn{4}{c}{ Canada - Post Adoption of IFRS (2015 to 2017) } \\
Variable & Obs. & Média & Std. Dev. \\
\hline MVE/SHR & 115 & 29,43 & 11,01 \\
BVA/SHR & 115 & 16,12 & 7,77 \\
E/SHR & 115 & 3,57 & 1,54 \\
D/SHR & 115 & 1,58 & 0,54 \\
RA/SHR & 115 & 4,76 & 2,74 \\
\hline
\end{tabular}


Panel B: Correlation Matrices (Pearson) - The matrices below were respectively segregated between Brazil ( $\mathrm{n}=268$ firm-observations) and Canada ( $\mathrm{n}=339$ firm-observations).

Brazil ( $\mathrm{n}=268$ firm-obs)

\begin{tabular}{lccccc}
\hline Variables & 1 & 2 & 3 & 4 & 5 \\
\hline 1 - MVE/SHR & 1,00 & & & & \\
2 - BVA/SHR & $0,99^{* * *}$ & $\mathbf{1 , 0 0}$ & & & \\
3 - E/SHR & $0,79^{* *}$ & $0,81^{* * *}$ & $\mathbf{1 , 0 0}$ & & \\
4 - D/SHR & $0,15^{* * *}$ & $0,19^{* * *}$ & $0,18^{* * *}$ & $\mathbf{1 , 0 0}$ & \\
5 - RA/SHR & $0,43^{* *}$ & $0,51^{* * *}$ & $0,18^{*}$ & $0,54^{* *}$ & 1,00
\end{tabular}

Canada ( $\mathrm{n}=339$ firm-obs)

\begin{tabular}{lccccc}
\hline Variables & 1 & 2 & 3 & 4 & 5 \\
\hline 1 - MVE/SHR & 1,00 & & & & \\
2 - BVA/SHR & $0,67^{* * *}$ & $\mathbf{1 , 0 0}$ & & & \\
3 - E/SHR & $0,48^{*}$ & $0,72^{* *}$ & 1,00 & & \\
4 - D/SHR & $0,13^{* * *}$ & $0,14^{* * *}$ & $0,15^{* * *}$ & $\mathbf{1 , 0 0}$ & \\
5 - RA/SHR & $0,68^{*}$ & $0,21^{* *}$ & $0,24^{*}$ & $0,08^{*}$ & $\mathbf{1 , 0 0}$ \\
\hline
\end{tabular}

*** Significant at $0.01-* *$ Significant at $0.05-*$ Significant at 0.10 .

In the Canadian sample, specifically regarding the pre and post-IFRS window comparison, it can be noted that there were not these significant declines in either market value (MVE/SHR) or in the accounting terms (BVA/ SHR, E/SHR, and D/SHR). This is perhaps an indication that the maintenance of regulatory assets through the issuance of IFRS 14 made it possible to maintain the average post-IFRS adoption accounting balances.

Regarding the correlations between the variables, obtained through Pearson's $\rho$ indicator and presented in Panel B of Table 2, we can verify a high association for both the Brazilian and Canadian datasets. This is not surprising, considering the theoretical model by Ohlson (1991), which indicates an association between the variables in the formation of the market value of companies.

Concerning the analysis of the ratio of book value of equity to the market value of the companies composing the sample, we elaborated Graph 1, which demonstrates the trends for both countries in the period from 2002 to 2016.

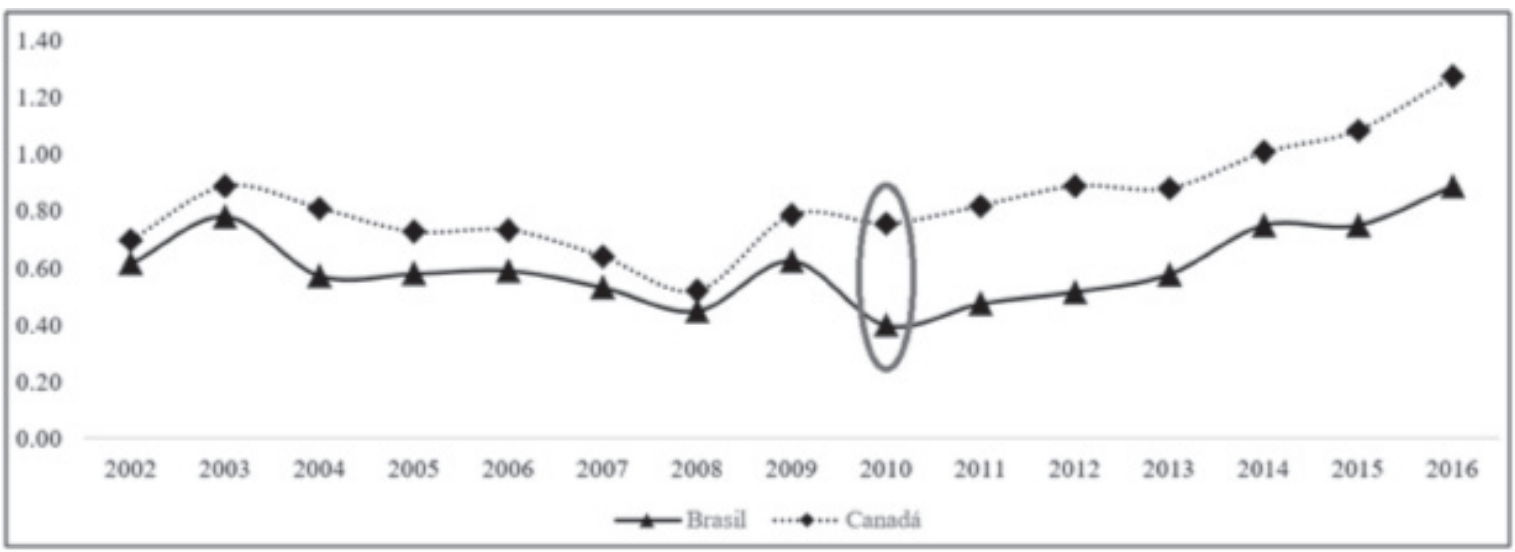

Graph 1. Book to Market Indicator (EQ/MV) 
It is possible to conceive that before 2010, both series have a similar path without abrupt displacements. However, in 2010, the year of the occurrence of the event studied, i.e. accounting derecognition of regulatory items in Brazilian companies' balance sheets, there is a drop in this trend due to a decline in the EQ/MV ratio for the informational set representing the Brazilian firms, which sees the ratio drop from around 0.7 in 2009 to about 0.4 in 2010 (a decline of 0.3). On the other hand, the representative trend of Canadian firms remains practically unchanged, at around 0.8. This shift began to decline around 2013, but there was a still significant gap from what it was in the pre-IFRS period, i.e. before 2010.

\subsection{Results for Hypothesis (1)}

The statistical estimates presented in Table 3 indicate the results for the test of the first hypothesis of this study.

Table 3

Panel Data Model Regressions - Brazilian Companies (Hypothesis 1)

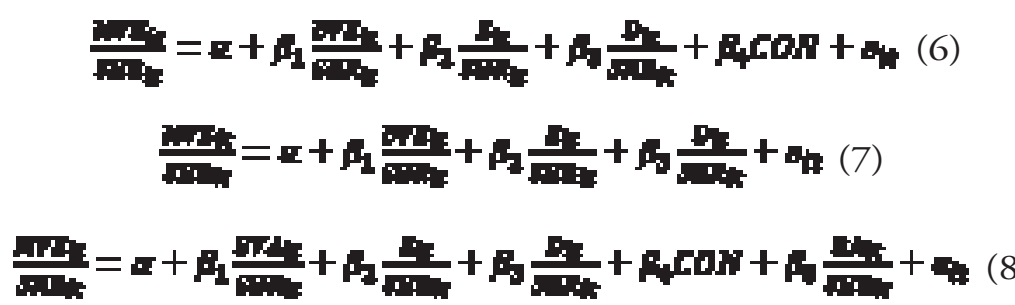

\begin{tabular}{|c|c|c|c|c|}
\hline \multicolumn{5}{|c|}{ Estimated Parameters ( $t$ statistics in parentheses) } \\
\hline \multirow{4}{*}{ Variables } & Sign & Eq. (6) & Eq. (7) & Eq. (8) \\
\hline & Expected & Pre-IFRS & Post-IFRS & Pre-IFRS \\
\hline & & 02 a 09 & 10 a 17 & 02 a 09 \\
\hline & & MVE & MVE & MVE \\
\hline \multirow[b]{2}{*}{$\beta_{1}$} & + & 0,51 & 0,32 & 0,48 \\
\hline & & $(67,6)^{* * *}$ & $(2,08)^{* *}$ & $(48,64)^{* * *}$ \\
\hline \multirow[b]{2}{*}{$\beta_{2}$} & + & 0,49 & 0,43 & 0,46 \\
\hline & & $(3,59)^{* * *}$ & $(3,56)^{* * *}$ & $(3,42)^{* * *}$ \\
\hline \multirow[b]{2}{*}{$\beta_{3}$} & + & 0,30 & 0,24 & 0,35 \\
\hline & & $(2,07)^{* *}$ & $(2,07)^{* *}$ & $(2,04)^{* *}$ \\
\hline \multirow[b]{2}{*}{$\beta_{4}$} & $?$ & 0,44 & - & 0,36 \\
\hline & & $(0,10)$ & - & $(0,08)$ \\
\hline \multirow[b]{2}{*}{$\beta_{5}$} & + & - & - & 0,29 \\
\hline & & & & $(81,42)^{* * *}$ \\
\hline Constant & & Yes & Yes & Yes \\
\hline Observações & & 160 & 108 & 160 \\
\hline $\mathrm{R}^{2}$ (Fixed Effects) & & $94,13 \%$ & $47,88 \%$ & $95,24 \%$ \\
\hline F-value for $\beta_{1}$ & - & - & $35,01^{* * *}$ & $36,18^{* * *}$ \\
\hline
\end{tabular}

*** Significant at $0.01-{ }^{* *}$ Significant at $0.05-*$ Significant at 0.10 . All variables were defined previously. Equation (3) was algebraically proposed by Ohlson (1991) and subsequently added to by Barth, Beaver, and Stinson (1991), by incorporating the deflation of the original terms by the volume of shares issued by each company $i$ at time $t$, as well as by the insertion of the error term $e_{i t}$ Equation (4) derives from Equation (3), differing only by the addition of a time dummy for 2008 and 2009, which denotes the phase of convergence to IFRS (CON). Finally, Equation (5) is notable for incorporating the $R A$ variable, which concerns regulatory assets, and is the main term analyzed in this article. The F-value presented refers to the comparison of the $\beta_{1}$ parameter, assuming the following null hypotheses: $\beta_{1}$ BVE Eq. (3) $=\beta_{1}$ BVE Eq. (4), as well as $\beta_{1}$ BVE Eq. (4) = $\beta_{1}$ BVA Eq. (5). 
Under this focus the most relevant term to be analyzed is the book value of equity, as denoted by the parameter $\beta 1$ in Equations (3) and (4). Comparing the estimated parameter for the BVE/SHR variable, it is verified that before the adoption of IFRS, this indicator was in the order of 0.51 , at less than $1 \%$ significance, and that after the new set of accounting rules this value decreased to 0.32 , at less than $5 \%$ significance. This reduction was statistically significant according to the F-value calculated for this parameter $\left(35.01^{* * *}\right)$, which indicates that the null hypothesis that the estimated BVE/SHR coefficients are equal before and after the IFRS in Brazil cannot be accepted. This implies the nonrejection of Hypothesis 1, which conjectures that there was a reduction in the informational value of the book value of equity against the market value of electrical energy distributors in Brazil after the adoption of IFRS.

The E/SHR and D/SHR variables denoted approximately estimated coefficients in the windows before and after IFRS. E/SHR fell from 0.49 to 0.43 , at less than $1 \%$ significance, and D/ SHR decreased from 0.30 to 0.24 , at less than $1 \%$ significance.

Concerning the effect of regulatory assets, a derivation of Equation (4), this effect was contemplated in the $\beta 5$ parameter. According to the results presented in the last column of Table 3 , it is found that the RA/SHR term denoted a coefficient in the range of 0.29 , at less than $1 \%$ significance. The relationship with the market value is positive and statistically significant. Again, a test was performed using the F-value, which verified that the $\beta 1$ parameter estimated from Equation (4), post-IFRS, was statistically different from the $\beta 1$ parameter estimated from Equation (5) with the regulatory assets, and the result indicates that these values are statistically different at less than $1 \%$ significance.

These results potentially indicate that no accounting record of regulatory assets implied a reduction in the relevance of the book value of equity to the market value of the electrical energy distributors, achieving the goals of financial statements announced by the IASB. This result can be corroborated deductively by the decisions made by ANEEL in 2010, allowing such amounts to be recognized in the regulatory statements (Res. 396/2010).

\subsection{Results for Hypothesis (2)}

Table 4 shows the results obtained from testing Hypothesis 2 . The most relevant term for this evaluation is the $\beta 5$ parameter, which refers to the RA/SHR variable. From this dependent variable, it is possible to verify that, economically, regulatory assets are more representative for the market value of Canadian companies than for Brazilian companies (0.72 and 0.29). However, in both samples the RA/SHR variable was statistically significant at less than $1 \%$, which is a similar result to that of Loudder, Khrunana, and Boastman (1996) for the United States. In addition, the F-value test presented a coefficient of 2.14, which should be understood as not enabling the rejection of the null hypothesis that the $\beta 5 \mathrm{RA} /$ SHR parameter (Brazil) is not statistically different from the $\beta 5 \mathrm{RA} / \mathrm{SHR}$ parameter (Canada). 
Table 4

Panel Data Model Regressions - Brazilian and Canadian Companies (Hypothesis 2)

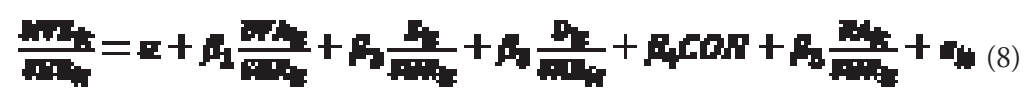

Estimated Parameters ( $t$ statistics in parentheses)

\begin{tabular}{|c|c|c|c|}
\hline & Sign & Brazil $^{\bigotimes}$ & Canada $^{\bigotimes}$ \\
\hline \multirow[t]{3}{*}{ Variables } & Expected & Pre-IFRS & Pre-IFRS \\
\hline & & 02 a 09 & 02 a 14 \\
\hline & & MVE & MVE \\
\hline \multirow{2}{*}{$\beta_{1}$} & + & 0,48 & 0,54 \\
\hline & & $(48,64)^{* * *}$ & $(6,45)^{* * *}$ \\
\hline \multirow{2}{*}{$\beta_{2}$} & + & 0,46 & 0,39 \\
\hline & & $(3,42)^{* * *}$ & $(4,06)^{* * *}$ \\
\hline \multirow{2}{*}{$\beta_{3}$} & + & 0,35 & 0,46 \\
\hline & & $(2,04)^{* *}$ & $(3,15)^{* * *}$ \\
\hline \multirow{2}{*}{$\beta_{4}$} & ? & 0,36 & - \\
\hline & & $(0,08)$ & - \\
\hline \multirow{2}{*}{$\beta_{5}$} & + & 0,29 & 0,72 \\
\hline & & $(81,42)^{* * *}$ & $(9,60)^{* * *}$ \\
\hline Constant & & Yes & Yes \\
\hline Observations & & 160 & 224 \\
\hline $\mathrm{R}^{2}$ (Within) & & $95,24 \%$ & $72,24 \%$ \\
\hline F-value for $\beta_{5}$ & & - & 2,14 \\
\hline
\end{tabular}

*** Significant at 0.01 - ** Significant at $0.05-*$ Significant at $0.10 . \Psi$ - results already presented in Table 3 , however estimated once again to perform the F-value test, which assumes as the null hypothesis $\beta_{5} \mathrm{RA}(\mathrm{Brazil})=\beta_{5} \mathrm{RA}(\mathrm{Canada})$. $0 \hat{\mathrm{i}}-\mathrm{it}$ is highlighted that the model applied to Canadian electric power companies does not include the CON variable because of the way IFRSs were adopted in that country, that is to say, without a transition phase as in the Brazilian case. According to Pacter (2017), Canadian companies that operate with rate-regulated activities started to prepare their consolidated financial statements under IFRS as of January 1, 2015. For more details presented in an objective way, we suggest consulting: https:// www.iasplus.com/en/jurisdictions/americas/canada.

From this result, it is not possible to reject Hypothesis 2 that before the adoption of IFRS regulatory assets had the same informational effect, from a statistical point of view, in Brazil and in Canada.

In general terms, regulatory assets were relevant to the market values of Brazilian and Canadian electricity companies, with no statistical differences between them, despite the economic environment being different. This result brings robustness to the argument that distinct economic environments per se do not necessarily imply different regulatory environments.

\subsection{Results for Hypothesis (3)}

The results presented in Table 5 denote the tests performed for Hypothesis 3. 
Table 5

Panel Data Model Regressions - Canadian Companies (Hypothesis 3)

\begin{tabular}{|c|c|c|c|}
\hline \multicolumn{4}{|c|}{ Estimated Parameters ( $\mathrm{t}$ statistics in parentheses) } \\
\hline \multirow{4}{*}{ Variables } & Sign & Canada $^{\Psi}$ & Canada \\
\hline & Expected & Pre-IFRS & Post-IFRS \\
\hline & & 02 a 14 & 15 a 17 \\
\hline & & MVE & MVE \\
\hline \multirow{2}{*}{$\beta_{1}$} & + & 0,54 & 0,63 \\
\hline & & $(6,45)^{* * *}$ & $(4,12)^{* * *}$ \\
\hline \multirow{2}{*}{$\beta_{2}$} & + & 2,11 & 1,61 \\
\hline & & $(4,06)^{* * *}$ & $(3,01)^{* * *}$ \\
\hline \multirow{2}{*}{$\beta_{3}$} & + & 0,46 & 0,14 \\
\hline & & $(3,15)^{* * *}$ & $(12,51)^{* * *}$ \\
\hline \multirow{2}{*}{$\beta_{4}$} & + & 1,41 & 2,44 \\
\hline & & $(9,60)^{* * *}$ & $(7,56)^{* * *}$ \\
\hline Constant & & Yes & Yes \\
\hline Observations & & 224 & 115 \\
\hline $\mathrm{R}^{2}$ (Within) & & $72,24 \%$ & $93,11 \%$ \\
\hline F-value for $\beta_{5}$ & & - & 5,68 \\
\hline
\end{tabular}

*** Significant at $0.01-* *$ Significant at $0.05-*$ Significant at $0.10 . \Psi$ - results already presented in Table 4, however estimated once again to perform the F-value test, which assumes as the null hypothesis $\beta_{1}$ BVA (Pre_IFRS) $=\beta_{1}$ BVA (Post_IFRS).

The most relevant term for verifying Hypothesis 3 is BVA/SHR, which denotes the book value of equity without the effect of regulatory assets. The comparison between the $\beta 1$ coefficients before and after IFRS indicates that there was a drop from 0.54 to 0.63 , although both remain statistically significant at less than $1 \%$. Also, the F-value indicates that these parameters are not statistically different from each other. As for the other variables, it should be noted that the behavior of the parameters remained close.

This test indicates that the advent of IFRS 14 very potentially led to Canadian electrical energy companies maintaining the relevance of the accounting information of their statements in regard to their market values, since a relevant element for this segment, regulatory assets, continued to be recorded in the financial statements as prior to the adoption of IFRS.

\subsection{Results obtained with the robustness tests}

The results presented in Table 6 refer to the statistical estimates derived from Equation (9) - the diff-in-diff model. 
Table 6

Differences-in-differences model robustness test

\begin{tabular}{|c|c|c|c|}
\hline \multicolumn{4}{|c|}{ Estimated Parameters ( $t$ statistics in parentheses) } \\
\hline \multirow{3}{*}{ Variables } & Sign & Eq. (9) & \\
\hline & Expected & 02 a 16 & \\
\hline & & MVE & \\
\hline \multirow{2}{*}{$\beta_{1}$} & + & 0,55 & \\
\hline & & $(45,41)^{* * *}$ & \\
\hline \multirow{2}{*}{$\beta_{2}$} & + & 2,16 & \\
\hline & & $(19,55)^{* * *}$ & \\
\hline \multirow[b]{2}{*}{$\beta_{3}$} & + & 0,15 & \\
\hline & & $(4,41)^{* *}$ & \\
\hline \multirow{2}{*}{$\beta_{4}$} & $?$ & $-9,16$ & \\
\hline & & $(-1,82)^{*}$ & \\
\hline \multirow{2}{*}{$\beta_{5}$} & ? & 1,22 & \\
\hline & & $(1,11)$ & \\
\hline \multirow{2}{*}{$\beta_{6}$} & $?$ & 2,40 & \\
\hline & & $(11,24)^{* * *}$ & \\
\hline \multirow{2}{*}{$\beta_{7}$} & $?$ & $-0,91$ & \\
\hline & & $(-7,48)^{* * *}$ & \\
\hline \multirow{2}{*}{$\beta_{8}$} & ? & 1,04 & \\
\hline & & $(1,25)$ & \\
\hline \multirow{2}{*}{$\beta_{9}$} & - & $-3,01$ & \\
\hline & & $(-62,35)^{* * *}$ & \\
\hline Year Fixed Effect & & Yes & \\
\hline Constant & & Yes & \\
\hline Observations & & 607 & \\
\hline $\mathrm{R}^{2}$ (Overall) & & $36,50 \%$ & \\
\hline
\end{tabular}

*** Significant at $0.01-{ }^{* *}$ Significant at $0.05-*$ Significant at 0.10

Focusing on the focal point of this test, which are the results obtained with the variable

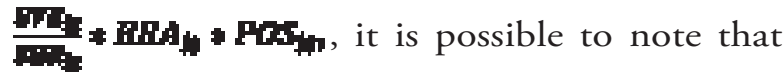
the parameter is negative (-3.01) and statistically significant at less than $1 \%$. This result indicates that the Brazilian distribution companies saw a reduction in the informational relevance of their book value of equity after the adoption of IFRS, compared with the companies of the same segment that operate in Canada, in terms of the value of their stock prices. These results are in line with the previous findings in Tables 1 to 6 .

Likewise, the insertion of the BRA term revealed an estimated parameter of -9.16 , significant at $10 \%$, which was used as a control variable for the purposes of fixed effects related to the jurisdictional environment in which the companies list their stocks. 
It is important to again emphasize the robustness of this test, since it controlled aspects of the market in which the companies act and also temporal effects $\left(\mathbf{2} \mathbf{H}_{\mathbf{m}} \mathbf{j}\right)$.

Regarding the recognition of part of the regulatory assets in the form of sectoral financial assets starting in 2014, due to the additions of contracts promoted by ANEEL and due to the issuance of OCPC 08, the results expressed in Table 7 below originated through the estimation of Equation (10).

Table 7

Sectoral Financial Assets Robustness Test - OCPC 08

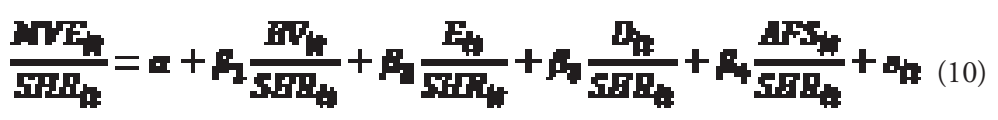

Estimated Parameters ( $t$ statistics in parentheses)

\begin{tabular}{|c|c|c|}
\hline \multirow{3}{*}{ Variables } & Sign & Eq. (10) \\
\hline & Expected & 10 a 17 \\
\hline & & MVE \\
\hline \multirow{2}{*}{$\beta_{1}$} & + & 0,45 \\
\hline & & $(42,11)^{* * *}$ \\
\hline \multirow{2}{*}{$\beta_{2}$} & + & 0,39 \\
\hline & & $(3,55)^{* * *}$ \\
\hline \multirow{2}{*}{$\beta_{3}$} & + & 0,35 \\
\hline & & $(2,07)^{* *}$ \\
\hline \multirow{2}{*}{$\beta_{4}$} & + & 0,13 \\
\hline & & $(0,79)$ \\
\hline Constant & & Yes \\
\hline Observations & & 160 \\
\hline $\mathrm{R}^{2}$ (Within) & & $83,11 \%$ \\
\hline
\end{tabular}

*** Significant at $0.01-* *$ Significant at $0.05-{ }^{*}$ Significant at 0.10 .

The results in Equation (10) are in line with the results of the estimation of Equation (7) in Table 4. From observing the principal term of interest of this robustness test, this being the variable

, which represents the amounts of sectoral financial assets for Brazilian distributors, recognized as of the promulgation of OCPC 08 in 2014 , it is possible to deduce that the estimated coefficient is positive in the order of around 0.13; however, no statistical significance was observed for the same value.

This result indicates that even after the recognition of part of the regulatory assets in the form of sectoral financial assets through the addition of contracts promoted by ANEEL and by the issuance of OCPC 08 , the accounting information derived from the balance sheets, that is, those issued in accordance with international financial reporting standards (IFRS), did not contain the same informational relevance in terms of the share prices for electricity distributors in Brazil.

Therefore, it is possible to consider an increase in validity for the other tests, especially for the model referring to Equation (7) and its statistical results, which indicate a fall in the relevance of the accounting information derived from shareholder's equity, after the adoption of IFRS, due to the write-off of regulatory assets. 


\section{Final Considerations}

The primary objective of this study was to verify if there were statistically significant reductions in the relevance of the accounting information of Brazilian electricity distributors because of the adoption of IFRS, which restricted the recognition of the sector's regulatory assets. The results corroborate this hypothesis.

In addition, Canadian electricity concessionaires were also studied, since at the time these companies adopted the international standards, IFRS 14 was already in force, which allowed such organizations to continue to record their regulatory assets. The statistical results indicated that the Canadian companies did not have the same reduction in the relevance of their financial statements to market values, potentially due to the effects of IFRS 14.

In terms of a direct comparison between the regulatory assets recorded in both jurisdictions, it was verified that before the adoption of IFRS, investors considered the regulatory assets of Brazilian and Canadian companies in the formation of stock prices. Likewise, the statistical results indicated that both the regulatory assets of the Brazilian distributors and of the Canadian firms were contained in their stock prices and that no statistically significant distinctions were found between the two countries, which implies the conclusion that in both cases the regulatory assets were seen as elements involved in the formation of the economic value of the companies studied, irrespective of the country.

In this context, it is possible to infer that the financial statements of Brazilian electrical energy distribution companies suffered a decrease in their informational relevance vis-à-vis the market value of these organizations after the adoption of IFRS, and that IFRS 14 potentially leveraged comparability distinctions between accounting statements emanating under the same accounting system for the same economic segment, which in theory is precisely the opposite of what was expected with the adoption of this accounting standard.
As indications for future studies, we suggest that other specific sectors be evaluated, such as banking institutions, insurance companies, private pension funds, and cooperatives, among others, whose local accounting standards are different from those advocated internationally.

\section{Nota}

1 To run the above test the two databases, Brazil and Canada, were compiled in a single one, noting that all information is dollarized and, therefore, there were no impacts of exchange rate variations.

\section{References}

Aboody, D.; Barth, M.; Kasznik, R. (2011). Revaluations of fixed assets and future firm performance: evidence from the UK. Journal of Accounting and Economics. 2011, v. 26, pp. 149-178.

ACSB. Rate-Regulated Activities. Sept. (2016). Available in: http://www.ifrs.org/Meetings/ MeetingDocs/ASAF/2016/September/1609ASAF-03A-Rate-regulated-Activities-Canada.pdf

Amir, E.; Harris, T. S.; Venuti, E. K. (1993). A comparison of the value-relevance of U.S. versus non-U.S. GAAP accounting measures using form 20-F reconciliations. Journal of Accounting Research. v. 31, n. 3, pp. 1-21.

Angrist, J. D., \& Pischke, J.-S. (2009). Mostly harmless econometrics: An empiricist's companion. Princeton: Princeton University Press.

Agência Nacional de Energia Elétrica. (2010). Resolução Normativa No 396. Brasília, DF.

Ball, R.; Brown P. (1968). An empirical examination of accounting income numbers. Journal of Accounting Research 6. pp. 159-178.

Ball, R., Li, X., Shivakumar, L. (2015). Contractibility and Transparency of Financial Statement Information Prepared Under IFRS: 
Evidence from Debt Contracts Around IFRS Adoption. Journal of Accounting Research. 53(5), pp. 915-963.

Barth, M. E.; Beaver, W. H.; Landsman, W. R. (2001). The relevance of the valuerelevance literature for financial accounting standard setting: Another View. Journal of Accounting and Economics. v. 39, pp. 77-104.

e C. Stinson. 1991 .

Supplemental data and the structure of thrift share prices. The Accounting Review 66 (January): 56-66

; Clinch, G. (2009). Scale effects in capital markest-based accounting research. SSRN Working Paper. Available in: <http://ssrn.com/ abstract $=201228>$. Accessed 20/01/2018.

Beaver, W.H. (1968). The information content of annual earnings announcements.

Journal of Accounting Research 6 (supplement), pp. 67-92.

(1997). Financial reporting: an accounting revolution, Prentice Hall.

CPC, C. d. (2014). OCPC 08 - Reconhecimento de Determinados Ativos e Passivos nos Relatórios Contábil-Financeiros de Propósito Geral das Distribuidoras de Energia Elétrica emitidos de acordo com as Normas Brasileiras e Internacionais de Contabilidade. nov. 2014. Available from: <http://www.cpc.org. br/CPC/DocumentosEmitidos/Orientacoes/ Orientacao Id $=99>$.

D'souza, J. M. (1998). Rate-regulated enterprises and mandated accounting changes: the case of electric utilities and post-retirement benefits other than pensions (SFAS No. 106). The Accounting Review, vol. 73, No. 3, pp. 387-410

Duarte, P. C. Lamounier, W. M. Takamatsu, R. T. Modelo econométricos para dados em painel: Aspectos teóricos e exemplos de aplicação à pesquisa em contabilidade e finanças. In:
CONGRESSO USP CONTROLADORIA E CONTABIlidAdE, 7., 2007, São Paulo. Anais eletrônicos... São Paulo: FEA-USP, 2007. Available from: <http://www.congressousp. fipecafi.org/artigos72007/523.pdf>

Easton, P. Eddey, P. H.; Harris, T. S. (1993). An investigation of reavaluations of long-lived assets. Journal of Accounting Research. v. 31, n. 1, pp. 1-38.

Francis, J.; Schipper, K. (1999). Have Financial Statements Lost Their Relevance? Journal of Accounting Research. n. 37, pp. 319-352.

Gordon, E.; Greiner, A.; Kohlbeck, M. J.; Lin, S.; Skaife, H. (2013). Challengens and Opportunities in Cross-Country Accounting Research. Accounting Horizons, 27, 141-154.

Holthausen, R.; Watts, R. (2001). The relevance of the value-relevance literature for financial accounting standard setting. Journal of Accounting and Economics. n. 31, pp. 3-75.

Horngren, C. T.; Harrison, W. T; Robinson, M. A. (1995). Accounting. 3. ed. New Jersey: Prentice Hall.

Houqe, M. N., Monem, R. M. (2016). IFRS Adoption, Extent of Disclosure, and Perceived Corruption: A Cross-Country Study. The International Journal of Accounting, 51, pp. 363-378.

IFRS. (2010). Conceptual Framework for Financial Reporting 2010. Available from: http:// www.ifrs.org/News/Press-Releases/Documents/ ConceptualFW2010vb.pdf.

IFRS. (2014). IFRS 14 Regulatory Deferral Accounts. Available from: http://www.ifrs.org/-/ media/feature/standards/taxonomy/historicalupdates/ir1-ifrs-14-regulatory-2014.pdf?la=en\& hash=2A0D5CBA7E1F7230275697A24E88E1 2A9B091AC9 
International Accounting Standards Board. (2017). Normas internacionais de relatório financeiro (IFRSs) 2017: incluindo as normas internacionais de contabilidade (IASs) e as interpretações tal como aprovadas em $1^{\circ}$ de janeiro de 2017. São Paulo: Instituto dos Auditores Independentes do Brasil, (Utilizado para Conceptual Framework e IFRS 14).

Lei no 10.438, de 26 de abril de 2002. Dispóe sobre a expansão da oferta de energia elétrica emergencial [...]. Brasília. DF: Diário Oficial da União.

Lei no 8.631, de 4 de março de 1993. Dispóe sobre a fixação dos níveis das tarifas para o serviço público de energia elétrica, extingue o regime de remuneração garantida e dá outras providências. Brasília, DF: Diário Oficial da União.

Lei no 8.987, de 13 de fevereiro de 1995. Dispóe sobre sobre o regime de concessão e permissão da prestação de serviços públicos previstos no art. 175 da constituição federal, e dá outras providências. Brasília, DF: Diário Oficial da União.

Lei no 9.427, de 26 de dezembro de 1996. Institui a Agência Nacional de Energia Elétrica - ANEEL, disciplina o regime das concessôes de serviços públicos de energia elétrica e dá outras providências. Brasília, DF: Diário Oficial da União.

Lei no 9.648, de 27 de maio de 1998. Altera dispositivos das Leis no 3.890-A, de 25 de abril de 1961, no 8.666, de 21 de junho de 1993, no 8.987, de 13 de fevereiro de 1995, no 9.074, de 7 de julho de 1995, no 9.427, de 26 de dezembro de 1996, e autoriza o Poder Executivo a promover a reestruturação da Centrais Elétricas Brasileiras - ELETROBRÁS e de suas subsidiárias e dá outras providências. Brasília, DF: Diário Oficial da União.

Lei no 11.638 , de 28 de dezembro de 2007. Altera e revoga dispositivos da Lei no 6.404, de 15 de dezembro de 1976, e da Lei no 6.385, de 7 de dezembro de 1976, e estende às sociedades de grande porte disposiçóes relativas à elaboração e divulgação de demonstrações financeiras. Brasília, DF: Diário Oficial da União.

Lima, J. B. N. (2010). A relevância da informação contábil e o processo de convergência para as normas IFRS no Brasil. Tese (Doutorado) - Faculdade de Economia, Administração e Contabilidade, Universidade de São Paulo, São Paulo.

Lopes, A. B. (2001). A Relevância da informação contábil para o mercado de capitais: o modelo de Ohlson aplicado à Bovespa. Tese (Doutorado) - Faculdade de Economia, Administração e Contabilidade, Universidade de São Paulo, São Paulo.

Lopes, A. B.; Walker, M. (2012). Asset revaluations, future firm performance and firm-level corporate governance arrangements: New evidences from Brazil. The British Accounting Review. n. 44, pp. 53-67.

Loudder, M. L.; Krurana, I. K.; Boatsman, J. R. (1996). Market Valuation of Regulatory Assets in Public Utiliy Firms. The accounting Review, Vol. 71, No. 3, pp. 357-373.

Martins, G. D.; Theóphilo, C. R. (2009). Metodologia da investigação científica para Ciências Sociais Aplicadas. São Paulo: Atlas.

Marques, L. D. (2000). Modelos dinâmicos com dados em painel: revisão de literatura. Faculdade de Economia do Porto, Portugal.

Ohlson, J. (1991). Earnings, book value, and dividends in security valuation. Working paper, Columbia University, New York, NY.

(1995). Earnings, book value, and dividends in equity valuation. Contemporary Accounting Research. n. 11, pp. 661-687.

Pacter, P. (2017). IFRS as global standards: a pocket guide. International Financial Reporting Standards Foundation: London. 
Parker, L. D.; Ferris, K. R.; Otley, D. T. (1989). Accounting for the human factor. London: Prentice-Hall.

Scott, W. R. (2012). Financial Accounting Theory. Toronto, Prentice Hall.

Tancini, G. R. (2013). Itens Regulatórios: um estudo aplicado à regulamentação tarifária da energia elétrica no brasil. Dissertação (Mestrado) - Faculdade de Economia, Administração e
Contabilidade, Universidade de São Paulo, São Paulo.

Torres, F. (2014). Brasil reage à norma sobre ativo regulatório que beneficia Canadá. Valor Econômico.

Wooldridge, J.M., 2010. Econometrics Analysis of Cross Section and Panel Data. CENGAGE Learning. 


\section{Authors:}

1. Eduardo Flores, PhD in Accounting at FEA-USP and PostDoc in Finance at EAESP-FGV. Professor at FEA-USP, Sao Paulo, Brazil. E-mail: eduardoflores@usp.br

ORCID

(iD) 0000-0002-5284-5107

2. Alexsandro Broedel Lopes, P.h.D in Accounting University of Manchester, England, UK United.l.

E-mail: broedel@usp.br

ORCID

(iD) 0000-0002-0702-4676

\section{Contribution of each author}

\begin{tabular}{lcc}
\hline Contribution & Eduardo Flores & Alexsandro Broedel \\
\hline 1. Definition of research problem & $\sqrt{ }$ & $\sqrt{ }$ \\
2. Development of hypotheses or research questions (empirical studies) & $\sqrt{ }$ & $\sqrt{ }$ \\
3. Development of theoretical propositions ( theoretical Work ) & $\sqrt{ }$ & $\sqrt{ }$ \\
4. Theoretical foundation/ Literature review & $\sqrt{ }$ & $\sqrt{ }$ \\
5. Definition of methodological procedures & $\sqrt{ }$ \\
6. Data collection & $\sqrt{ }$ & $\sqrt{ }$ \\
7. Statistical analysis & $\sqrt{ }$ & $\sqrt{ }$ \\
8. Analysis and interpretation of data & $\sqrt{ }$ & $\sqrt{ }$ \\
9. Critical revision of the manuscript & $\sqrt{ }$ & $\sqrt{ }$ \\
10. Manuscript Writing & $\sqrt{ }$ \\
11. Other (please specify which) & & \\
\hline
\end{tabular}

\section{Erratum}

Where was written:

"Review of Business Management, São Paulo, v.21, n.5, p.928-952, oct/dec. 2019.”

Now read:

“Rev. Bras. Gest. Neg. São Paulo v.21 n.4 oct-dec. 2019 p. 928-952” 